Okajimas Fol. anat. jap., 49 : 111-128, 1972

\title{
Studies on the Functional Morphology and Anatomy of the Central Nervous System of Xenentodon cancila (Ham.) including its Histology \\ 1. The Brain
}

By

\author{
O.P. Gupta and R. K. Shrivastava
}

(with 3 text figures and 3 plates)

Department of Zoology, University of Saugar,

Sagar (M. P.) India

-Received for Publication, January 10, 1972-

\section{Introduction}

The nervous system of fishes and the related sense organs have been of much interest to the workers due to the variety of feeding habits and their various aquatic adaptations. Apart from the surface anatomy the internal detailed structure has been worked out mainly by Ariens Kappers (1906, '11, '12). In India works of Karandiker and Thakur (1951), Marathe (1937, '55), Sinha (1964), Mookerji and others (1950), Bhimachar (1935, '37, '45), Maheswari (1965) and Saksena (1965) are noteworthy. The purpose of this paper is to describe in details the morphology and anatomy along with histology of the brain of Xenentodon cancila (Ham.), which is remarkable in its shape, its feeding and hunting habits. It is related to the family Exocoetidae.

Discussion and the functional aspects are dealt with the description of the individual organs and as such a separate section on discussion was found unnecessary.

\section{Material and Methods}

The material for this work was collected locally from Sagar lake. For studying the morphology or brain, heads of larger specimens were exposed partly from dorsal, ventral and lateral sides and then they were kept in $10 \%$ formalin solution. The dissections were made after a few days to expose the brains. Studies of the gross morphology of the brain were made under the binocular microscope. The 
anatomy and the histology of brain were studied by preparing serial transverse $(5 \mu, 10 \mu)$, longitudinal $(5 \mu, 10 \mu)$ and borizontal sections $(15 \mu)$ of the brain. Transverse and longitudinal sections were stained by Roger's silver method (1931), Pal-Weigert (Clark and Ward, 1934). The horizontal sections were dealt with according to the Golgi's silver method (1905).

\section{Results}

The brain of Xenentodon is an elongated structure showing various regions. It is securely placed inside the cranium. It is covered by an epithelial covering membrane which is highly vascular. This covering membrane forms the meninx primitiva. The brain of Xenentodon may be divided into following parts:
(i) Telencephalon
(ii) Diencephalon
(iii) Mesencephalon
(iv) Rhombencephalon
(a) Metencephalon
(a) Myelencephalon.

\section{(i) Telencephalon}

The telencephalon includes - the olfactory lobes and the cerebrum. The olfactory lobes (OLF. L. Figs. 1A and 2) are placed just in front of the cerebrum. The two olfactory lobes are swollen rounded structures. The olfactory nerves (OLF. T. Fig. 3) from the olfactory epithelium end into them (Gupta, 1971). The main mass of each olfactory lobe is formed of nerve fibres and large-sized mitral cells (MIT. C. Figs. 4 and 5). There are no olfactory peduncles in Xenentodon, but they are reported in Cyprinidae and Siluridae (Mookerjee and others, 1950). The olfactory lobes which are said to be developed according to the sense of smell in fishes, decrease in size which also points that Xenentodon is a surface dweller.

The cerebrum (CER. Figs. 2, 3 and 12) is of average size. It is divided into three lobes namely the axial or frontal (AX. L. Fig. 12), the parietal (PAR. L. Figs. 1A and 12) and the occipital (OC. L. Figs. $1 \mathrm{~A}$ and 3). A median longitudinal groove on the dorsal side separates the above lobes of the two sides. The frontal lobe (AX. L. Fig. 12) lies just laterally to the mid-dorsal groove. The frontal lobe also known as the axial lobe which is mainly olfactory in function (A. Kappers et al., 1936), is demarcated from the parietal lobe by a frontal fissure (FR. FIS. Fig. 12) laterally. These lobes which are 


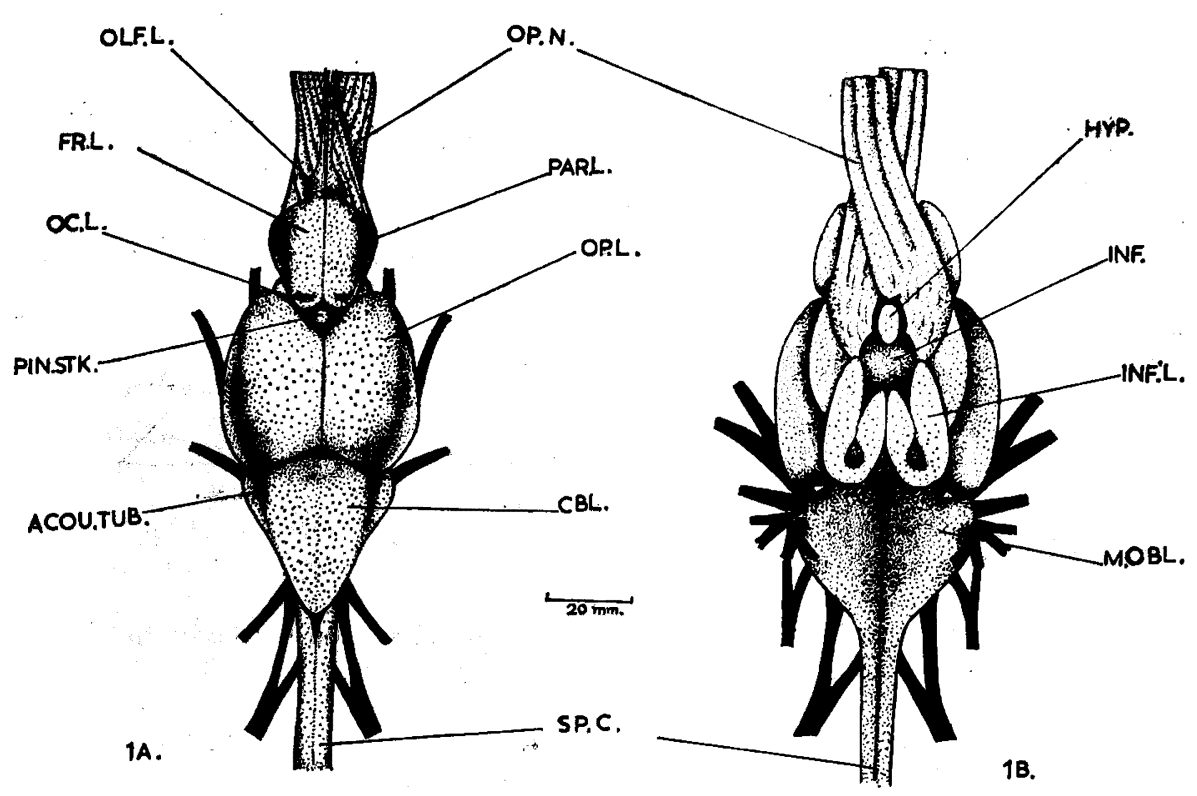

Fig. 1A. Dorsal view of the brain of Xenentodon.

1B. Ventral view of the brain of Xenentodon.

better developed in Notopterus, are observed small in Xenentodon. An occipital fissure separates it posteriorly from the occipital lobe. The occipital lobe (OC. L. Figs. $1 \mathrm{~A}$ and 3) is a small rounded or swollen structure just behind the frontal lobe. A rhinal fissure (RHI. FIS. Fig. 12) lies in between the frontal and the olfactory lobes. The frontal and occipital fissures are situated on the dorsal side of the telencephalon while the rhinal fissure is situated on the ventral side.

The cerebral hemispheres (CER. Figs. 2, 3 and 12) are characterised by the presence of a single median and narrow ventricle (LAT. V. Fig. 2). It represents the two lateral ventricles found in other fishes. This ventricle is narrow due to the thickening of the pallium (dorsal part), lateral walls and the base of the telencephalon. The ventricle is lined by the ependymal cells.

The walls of the cerebrum are not differentiated into strata. The radiating (RAD. NF. Fig. 8) nerve fibres with scattered neurons are found in it. At places the cells are concentrated peripherally which appear to form a sort of granular layer (GR. L. Fig. 8).

\section{(ii) Diencephalon}

Its limits are demarcated by the velum transversum (V. T. Fig. 7) infront and by the posterior commissure (POST. COMM. Fig. 10) behind. Very little portion of the diencephalon is visible on the dorsal side. Though small in size, it has a number of important structures. 




$20 \mathrm{~mm}$.

Fig. 2. Camera lucida sketch of a longitudinal section of the brain of Xenentodon showing the ventricles.

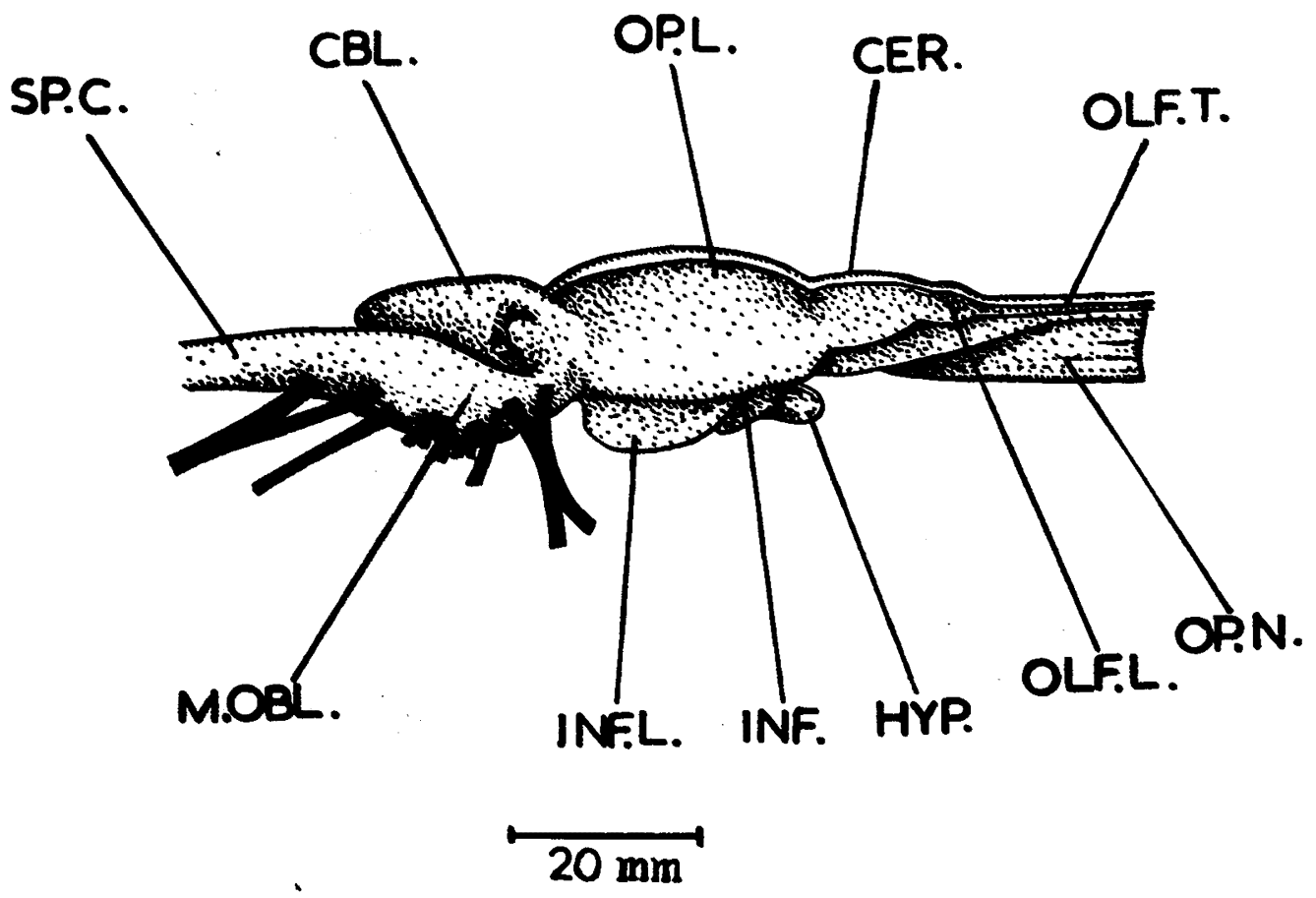

Fig. 3. Lateral view of the brain of Xenentodon. 
The cavity of the diencephalon is known as the third ventricle (III. V. Fig. 11). The ventral limit between the diencephalon and telencephalon is shown by the recessus preopticus (REC. PR. OPT. Figs. 2 and 12). The position of the recessus is indicated by the large-sized nucleus preopticus (N. PR. OPT. Fig. 12) which lies just above it.

Herrick (1892) divides the vertebrate diencephalon into four regions, which can also be recognised in Xenentodon as follows:

(a) Epithalamus: The epithalamus is formed by two large oval bodies on either side of the median line known as the habenular ganglia (HAS. G. Figs. 7 and 13).

(b) Ventral thalamus: This part of the diencephalon is represented by the region near about the nucleus rotundus (N. ROT. Figs. 14 and 15).

(c) Dorsal thalamus: It is poorly developed in Xenentodon. It forms the main centre of the optic fibres of the higher vertebrates but in teleosts it is insignificant.

(d) Hypothalamus: The floor of the third ventricle is designated by the torm hypothalamus. In Xenentodon it is well developed. The special structures seen in the hypothalamic region are the infundibulum (INF. Figs. 1B, 2 and 11), the hypophysis (HYP. Figs. 1B, 2, 3, 11 and 13) and the lobi inferiores (INF. F. Figs. 2, 3,15 and 16). The lobi inferiores are thick-walled evaginations from the bottom of the third ventricle. They run backwards from the diencephalon. The two lobi inferiores are placed close together. There is no median saccus vasculosus. It is present in Notopterus notopterus (Mookerje日 and others, 1950).



Dammerman (1910) considers the saccus vasculosus as related to the aquatic life of the fishes living at great depths. Xenentodon lives only in the lighted region of the waters and thus absence of the 
saccus vasculosus appears to confirm the views of Dammerman.

Infundibulum appears as a recessus of the third ventricle (INF. V. Figs. 2 and 16). Externally it appears as a large ovoid body. The cavity of the infundibulum is continued into the hypophysis. In front of the hypophysis is the optic chiasma (OP. N. Figs. 1A, 1B, $2,3,5$ and 12) where the optic nerves of two sides decussate.

Hypophysis or pituitary body (HYP. Figs. 1B, 2, 3, 11 and 13) is described in detail along with the endocrine organs (Gupta and Shrivastava, 1971).

\section{Parietal region of Diencephalon:}

The parietal region is limited in front by the velum transversum and behind by the posterior commissure. The velum transversum (V. T. Fig. 7) is a fold hanging from the roof of the third ventricle. The velum transversum is mainly made up of ependymal epithelium and connective tissue. It is absent in Siluridae (Cordier, 1939). The roof of the diencephalon near about the velum transversum is membranous. In Xenentodon it shows only minor folds and some vascularisation. The anterior choroid plexus is thus poorly developed. The velum transversum and the roof of the diencephalon are transformed into a real choroid plexus in Gobiidae, Blenidae and Gastrosteus, etc. (Cordier, 1939).

The special structures found on the roof of the diencephalon are:

(a) Paraphysis: It is an outgrowth of the roof in front of the velum transversum. It is present in Belone (Friedrich-Freksa and Studnicka, 1932). However, it could not be ascertained in the adult of the Xenentodon. A small evagination is seen in front of the velum transversum but it may well be one of the many minor folds seen in this region (PAR. Fig. 7).

Behind the velum transversum is seen the well developed pineal body (PIN. Figs. 2, 6, 7, 11 and 13). The parapineal is absent.

(b) The pineal body (PIN. Figs. 2, 6, 7, 11 and 13) is an elongated, folded glandular structure lying on the dorsal side of the diencephalon. It is made up of ependymal cells placed on a basement or limiting membrane. Some of the ependymal cells are modified into the neurosensory cells. The neurosensory cells (NSC. Fig. 9) are elongated and show tail-like processes on both ends. The inner process forms a sort of sensory hair while the outer processes are continued into the pineal nerve. The remaining ependymal cells function as supporting cells. Large-sized cells near the limiting membrane are the ganglion cells (GANG. C. Fig. 9). An important feature in the pineal body of Xenentodon is the presence of numerous pigment granules in the pineal cells. The lumen of the pineal body is filled with rounded cells 
which appear to have been derived from the general ventricular (ependymal) epithelium.

\section{(iii) Mesencephalon}

In the mesencephalon the main structure is the tectum opticum (optic lobes). The tectum opticum (TEC. OPT. Figs. 13, 15, 16, 17 and 18) is divided into two by a median longitudinal groove into two symmetrical halves known as corpora bigemini or the optic lobes. The optic lobes (OPT. L. Figs. 1A, 2 and 3) in Xenentodon are of large size and thick walled. On either side of the median line, on the ventricular surface are two ridge-like structures which form the tori longitudinales (T. LONG. Fig. 13).

Further, the cavity of the tectum opticum, specially in the posterior half is filled with two outgrowths. Each one is known as the torus semicircularis (T. SEM. Fig. 14). The ventral part of the mesencephalon is known as the tegmentum. The main feature of the tegmentum is the formation of the posterior commissure in its anterior part. The fibres of the posterior commissure actually arise from the cells in the tegmentum and from thence, they run upwards forming a transverse structure known as posterior commissure (POST. COMM. Fig. 10). It is the anterior limit of the mesencephalon. The optic tectum is the main structure of the brain in Xenentodon where the fibres of the optic nerves end. The tectum opticum or the optic lobes which are said to be connected with the size of eye and visual activity of the fishes (White, 1948; Evans, 1937) are found well developed and large in Pollack, a day hunter (Evans, 1940) and sight feeder like Catla (Mookerjeo et al., 1950). In Xenentodon, which is a surface dweller and sight feeder also, these lobes are found large in size.

The tectum opticum is formed of three main layers. The superficial layer (SUP. L. Figs. 13, 15, 16, 17 and 18) contains a number of neurons. These neurons (NEU. Fig. 18) send out axons towards the inner side, which pass through the fibres of the optic tract (middle layer) and reach upto the granular layer. The middle layer (MID. L. Figs. 13 and 17) which follows the superficial layer is mainly a mass of nerve fibres with some scattered neurons. The fibres come from the retina of the eye. The innermost layer is the granular (GRA. L. Figs. 13, 15 and 17) one containing the rounded cells.

\section{(iv) Rhombencephalon}

It is divided into metencephalon (cerebellum) and the myelencephalon (medulla oblongata).

The cerebellnm (CBL. Figs. 1A, 2 and 3) is roughly traingular in 
shape from the dorsal side. The cerebellum, which is responsible for the quickness of motion by the body of fish, is found large in Brama (Evans, 1940). It is found prominent and triangular but comparably smaller in Xenentodon. Its antero-lateral corners form the acoustic tubercles (ACOU. TUB. Fig. 1A). The acoustic tubercles, which are related with lateral line canal for the direction findings are observed small in Xenentodon.

The wall of the cerebellum is made up of an outer plexiform layer or molecular layer (MOL. L. Figs. 19 and 20). This layer shows a network of intermingled fibres. Just below the plexiform layer are found a number of cell bodies. By the Golgi (1903) method these cell bodies are found to be actually the Purkinje cells (PUR. C. Fig. 20). The purkinje cells send out numerous processes into the plexiform layer (PLEX. L. Fig. 19) and go upto the outer limit. The innermost layer of cerebellum consists of rounded cells forming the granular layer (GRAN. L. Fig. 19).

In Siluridae, the cerebellum is directed rostrally above the tectum opticum while in other teleosts it is inclined backwards.

The cerebellum throws out an anterior extension which penetrates into the cavity of the mesencephalon just below the tectum opticum. This structure is known as the valvula cerebelli (VOL. Figs. 2 and 17). The valvula cerebelli is bifurcated anteriorly. The bifurcated portion is folded upon itself. According to Herrick (1891) this structure which is said to be directly proportional to the activeness of the animal, is well developed in Xenentodon. In Mormyridae (Cordier, 1938), its development is described as simply monstrous. The cavity of fourth ventricle extends into the cerebellum (META. Fig. 2).

Behind and below the cerebellum lies the medulla oblongata. It is the enlarged portion of the spinal cord. The cavity inside is known as the fourth ventricle. Its roof is quite thin and is made up of ependymal epithelium and the meningeal tissue. This thin membranous roof gives out a number of papillae which hang into the ventricle. These papillae are highly vascularised and form the posterior choroid plexus.

\section{Abstract}

The brain of Xenentodon is divided into the telencephalon (olfactory lobes and cerebrum), diencephalon, mesencephalon and rhombencephalon (cerebellum and medulla oblongata). Olfactory lobes are small and the olfactory peduncles are absent. Cerebrum is divided into axial, parietal and occipital lobes by rhinal, occipital and frontal fissures. There is a single median and narrow ventricle in the 
cerebrum. Diencephalon is demarcated by a velum transversum in front and by the posterior commissure behind. Out of four regions of the diencerhalon (epithalamus, ventral thalamus, dorsal thalamus and hypothalamus), dorsal thalamus is poorly developed. Haebenular ganglia form two large ovoid masses in the epithalamus. The hypothalamus is very well developed with an infundibulum and the lobi inferiores. There is no saccus vasculosus. On the roof of diencephalon there is some indication of the paraphysis but parapineal is absent. The pineal is an elongated structure with a definite stalk. Numerous pigment granules are found in the pineal cells. Tectum opticum is divided into two lobes. Torus semicircularis and tori longitudinales are well developed. The cerebellum is roughly triangular in shape. Its anterolateral corners form the acoustic-tubercles. The cerebellum throws out an anterior extension, the valvula cerebelli, into the cavity of mesencephalon. The valvula cerebelli are biforcated anteriorly. Posterior choroid plexus is more developed than the anterior choroid plexus.

\section{Acknowledgement}

We are thankful to Dr. H.N. Bhargava, Head of the Department of Zoology for providing us the necessary facilities.

\section{References}

Ariens Kappers, C. U., 1906. The structure of teleostean and selachian brain. J. Comp. Neur. and Psy., 16 : 1-112.

Bhimachar, B.S., 1935. A study of the correlation between the feeding habits and the structure of hind brain in the South Indian cyprinoid fishes. Proc. Roy. Soc. London 117 ' $\mathrm{B}$ ' : 258-272.

- 1937. A study of the medulla oblongata of cyprinodont fishes with special reference to their feeding habits. Proc. Roy. Soc. London 123 ' B': $59-68$.

Cordier, R., 1938. Sur les organs sensoriels cutanés du Mormyridaé. Gnathonemus monteiri. Ann. Soc. R. Zool. Belgique, Vol. 68, p. 77-90.

-1939 . Les composants functionnels des nerfs oràniens ches les Vertébratés. Actualitès Scient. Indust., Paris No. 797, p. 56.

Dammerman, K. W., 1910. Der saccus vasculosus der Fische, ein Tiefeorgan. Zeits. Wiss. Zool., Vol. 96, p. 654-726.

Davenport, H. A., 1960. Histological and Histochemical Techics. Saunders Co. Philadelphia.

Evans, H. M., 1940. Brain and body of fish. A study of brain pattern in relation to hunting and feeding in the fish. London $164 \mathrm{pp}$.

Friedrich-Freksa, H., 1937. A comparative study of the brain in Pleuronectidae. Proc. Roy. Soc. London 122 ' B': 308-343.

- 1932 . Entwickelung, Bau und Bedentung der Parietalgegend bei Teleosteern. Zeit. Wiss. Zool., Vol. 141, p. 52-142.

Gray, P., 1953. The Microtonist's Formulary and Guide. Blakiston Company, Inc. 
New York.

Golgi, 1903. Golgi, Camillo, Opera omnia 3 Vol. Milạ, Hoepli (Fide' Gray, 1953).

Gupta, O.P., 1972. On the origin and innervation of the cranial, spinal and the autonomic nervous system of the Indian Gar-pike, Xenentodon cancila (Ham.) Anat. Anz. Jena, Bd 131, S. 39-50.

- and Shrivastava, R. K., 1971. On the location and the histology of the endocrine glands in Xenentodon cancila (Ham.) Okaj. Fol. anat. jap., Band 48, Heft 4, S. $189-203$.

Herrick, C. J., 1891a. Contribution to the morphology of the brain of the siluridae and ganoids. J. Comp. Neur., $1: 211-245$.

, 1891b. Brain of some American fresh water fishes. J. Comp. Neurol., 2: 228-245.

, 1892. Additional notes on teleost brain. Anat. Ans., 7: 422-471.

Karandikar, K. P. and Thakur, T. P., 1951. Morphology of Sciaenoides brunneus (Day). Univ. Bombay, Zool. Mem. No. 3: 71-80.

Maheswari, S. C., 1965. The cranial nerves of Mastacembelus armatus. Jap. J. Ichthyology, $12(3 / 6): 89-98$.

Marathe, V. B., 1955. The nervous system of Psendorhombus arsius. J. Univ. Bombay, $23: 60-73$.

Mukerjee, H. K., Mukerjee, P.S. and Ganguly, D. N., 1950. Study on the structure of the brain of some Indian fishes in relation to their feeding habits. Proc. Zool. Soc. Bengal, 3 : 119-153.

Rogers, 1931. Anatomical Record, Philadelphia Vol. 49 : p. 81 (fide’ Davenport, 1960).

Saxena, P.K., 1965. The structure of brain and its correlation with the habits on Clarias batrachus. Proc. Zool. Seminar. Vikram Univ. Ujjain, 179-185.

Sinha, B. M., 1966. The brain of Wallago attu. Proc. Nat. Acad. Sci. India. XXXVI 4 (b) : 565-570.

Weigert, Pal., 1934. Stain Technology, Geneva Newyork, Vol. 9 : p. 34 (fide' Davenport, 1960).

White, E. L., 1948. An experimental stady of the relationship between the size of the eye and the optic tectum in the brain of the developing teleost Fundulus heteroclitus. J. Exp. Zool. $108: 439-465$.

\section{Abbreviations}

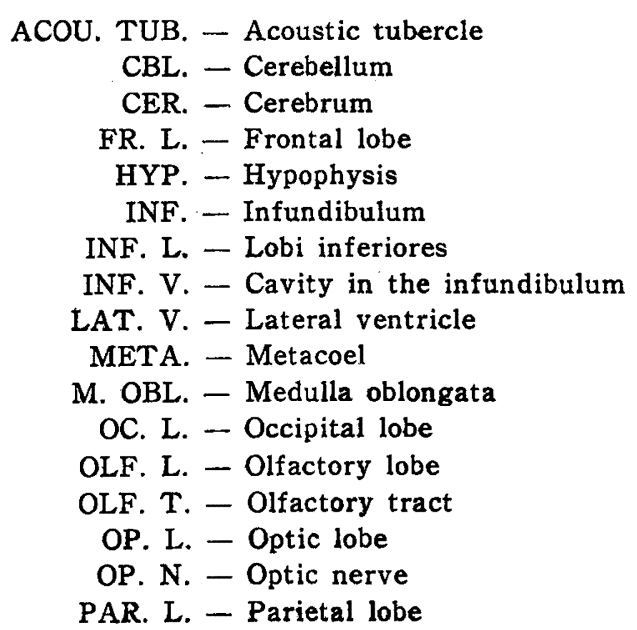


PIN. - Pineal

PIN. STK. - Pineal stalk

REC. HYP. - Recessus hypophysis

REC. P. OPT. - Recessus preopticus

SP. C. - Spinal cord

VOL. - Valvula cerebelli

III. V. - Third ventricle

IV. V. - Fourth ventricle 


\title{
Explanation to Plate I
}

Fig. 4. Xenentodon, $35 \mathrm{~mm}$. W. 1. : T.S. passing through olfactory region of the brain showing the mitral cells. $\times 60$

Fig. 5. Xenentodon, adult : L.S. of telencephalon. $\times 60$

Fig. 6. Xenentodon, $35 \mathrm{~mm}$. W.1.: T.S. of telencephalon showing different lobes of cerebrum. (Roger's Silver stain) $\times 60$

Fig. 7. Xenentodon, adult : L.S. showing velum transversum, paraphysis, pineal and haebenular ganglia. $\times 36$

Fig. 8. Xenentodon, adult : L. S. of cerebrum. (Pal-Weigert stain) $\times 60$

Fig. 9. Xenentodon, adult: A portion of the T.S. of pineal body. $\times 270$

Fig. 10. Xenentodon, $35 \mathrm{~mm}$. W.1.: T.S. passing through tectum opticum and the infundibulum. $\times 60$

Fig. 11. Xenentodon, $35 \mathrm{~mm}$. W. 1. : T.S. passing through tectum opticum, pineal and pituitary bodies. $\times 60$

\author{
Abbreviations \\ AX. L. - Axial or frontal lobe \\ CER. - Cerebrum \\ FR. FIS. - Frontal fissure \\ GANG. C. - Ganglion cells \\ GR. L. - Granular layer \\ HAB. G. - Haebenular ganglion \\ HYP. - Hypophysis \\ INF. - Infundibulum \\ LAT. V. - Lateral ventricle \\ MIT. C. - Mitral cells \\ NS. C. - Neurosecretory cells \\ OLF. L. - Olfactory lobe \\ OP. CL. - Optocoel \\ OP. L. - Optic lobe \\ OP. N. - Optic nerve \\ PAR. - Paraphysis \\ PAR. L. - Parietal lobe \\ PIN. - Pineal \\ PIN. STK. - Pineal stalk \\ POST. COMM. - Posterior commissure \\ RAD. NF. - Radiating nerve fibres \\ RHI. FIS. - Rhinal fissure \\ TEC. OPT. - Tectum opticum \\ V. T. - Velum transversum \\ III. V. - Third ventricle
}




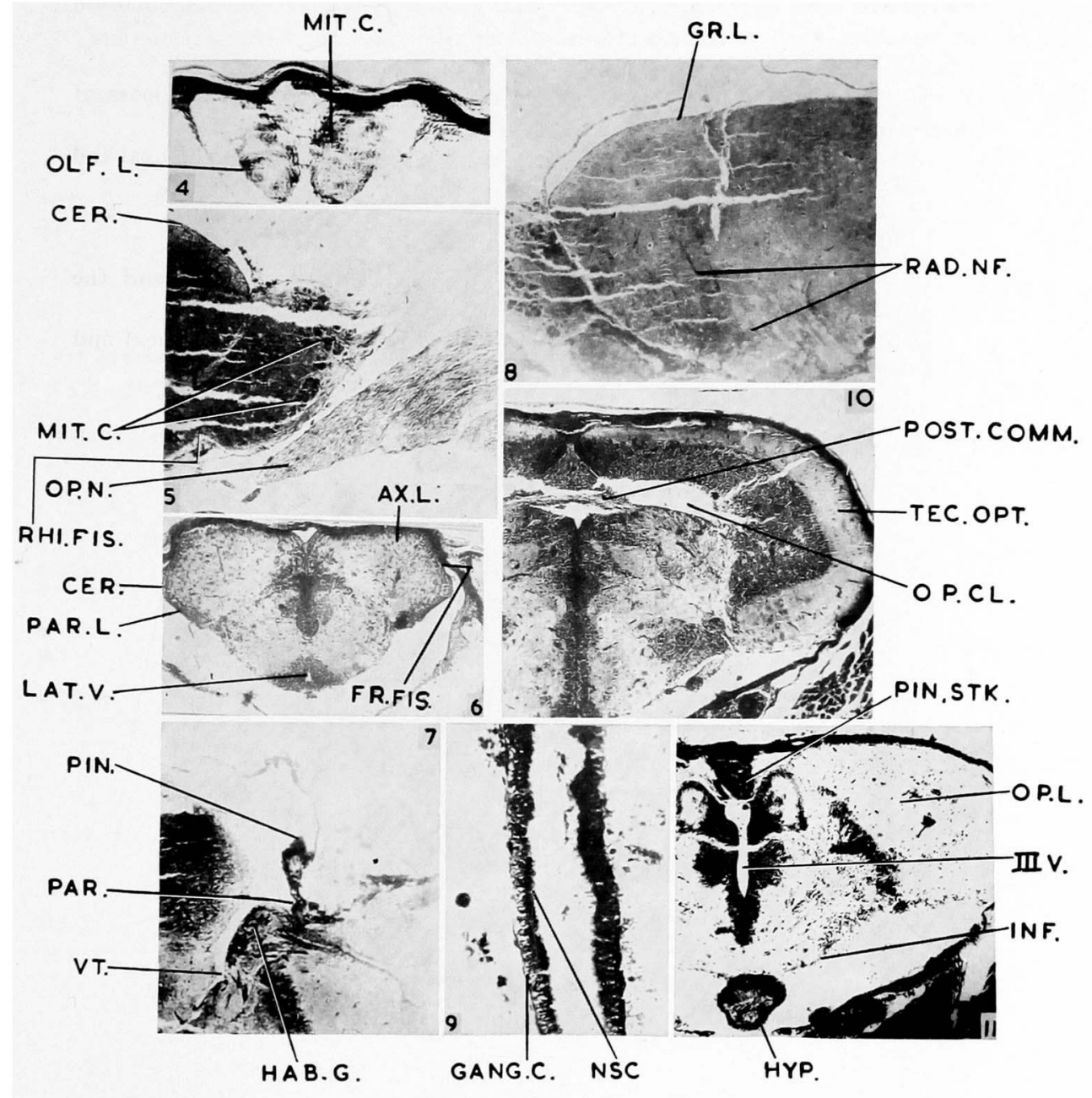

O. P. Gupta 


\title{
Explanation to Plate II
}

Fig. 12. Xenentodon, adult: L.S. showing the recessus preopticus and the nucleus preopticus. $\times 60$

Fig. 13. Xenentodon, adult: T.S. of diencephalon passing through the region of the pineal and pituitary bodies. $\times 36$

Fig. 14. Xenentodon, adult: L.S. of mesencephalon showing the nucleus rotundus (Roger's Silver stain) $\times 36$

Fig. 15. Xenentodon, $35 \mathrm{~mm}$. W. 1. : T.S. passing through the tectum opticum and lobi inferiores. $\times 60$

\author{
Abbreviations \\ CER. - Cerebrum \\ GRA. L. - Granular layer \\ HAB. G. - Haebenular ganglia \\ HYP. - Hypophysis \\ INF. C. - Infundibular cavity \\ INF. L. - Lobi inferiores \\ MID. L. - Middle layer \\ N. PR. OPT. - Nucleus preopticus \\ N. ROT. - Nucleus rotundus \\ OP. CL. - Optocoel \\ OP. N. - Optic nerve \\ PIN. - Pineal body \\ REC. HYP. - Recessus hypophysis \\ RE. PR. OPT. - Recessus preopticus \\ SUP. L. - Superficial layer \\ TEC. OPT. - Tectum opticum \\ T. LONG. - Torus longitudinalis \\ III V. - Third ventricle
}






O. P. Gupta 


\title{
Explanation to Plate III
}

Fig. 16. Xenentodon, $35 \mathrm{~mm}$. W.1. : T. S. passing through tectum opticum and infundibular ventricle. $\times 36$

Fig. 17. Xenentodon, adult: L.S. of mesencephalon showing valvula cerebelli and layers of tectum opticum. (Roger's Silver stain) $\times 36$

Fig. 18. Xenentodon, adult: H.S. of tectum opticum showing neurons with axonic fibres directed towards inner side. (Golgi's stain). $\times 120$

Fig. 19. Xenentodon, adult: L.S. of cerebellum showing different layers. (PalWeigert stain). $\times 60$

Fig. 20. Xenentodon, adult: H.S. of cerebellum showing molecular layer and the purkinje cells sending out numerous processes into the inner plexiform layer. (Golgi's stain)

\author{
Abbreviations \\ GRA. L. - Granular layer \\ GRAN. L. - Granular layer \\ INF. L. - Lobi inferiores \\ INF. V. - Cavity in the lobi inferiores \\ MID. L. - Middle layer \\ MOL. L. - Molecular layer \\ PLEX. L. - Plexiform layer (inner side) \\ PUR. C. - Purkinje cells \\ SUP. L. - Superficial layer \\ T. SEM. - Torus semicircularis \\ VOL. - Valvula cerebelli
}


Plate III

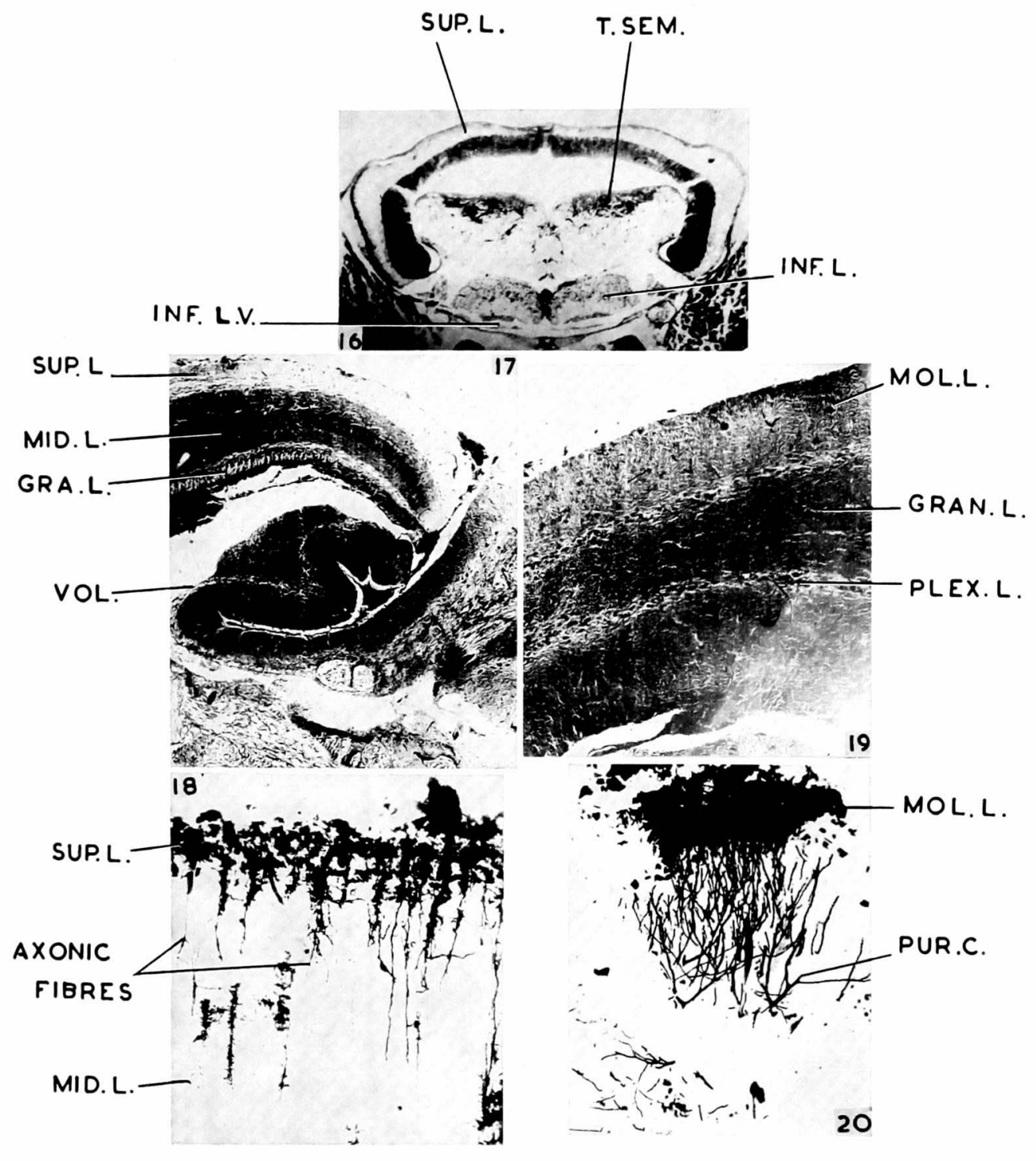

O. P. Gupta 